\title{
Collecting Consumer Debt in America
}

\author{
BY ROBERT M. HUNT
}

hy should economic scholars study the

consumer debt collection process? First,

the cost and effectiveness of the collections

process has implications for the pricing

and availability of consumer credit. Second, changes

in technology and the structure of credit markets have

transformed the collections industry. Small mom-and-

pop operations are increasingly being replaced by firms

operating nationally, collecting on billions of dollars in

bad debt purchased from creditors. In this article, Bob

Hunt explores how creditors and their agents attempt to

collect past-due consumer debt, particularly unsecured

debt. Creditors have a number of remedies open to them,

but their effectiveness is limited by the fact that consumers

can file for bankruptcy. Even outside of bankruptcy,

consumers enjoy a variety of legal protections, including

some they may not be aware of.

When consumers fall behind on their bills, their accounts are eventually sent to collections. Most lenders and some nonfinancial businesses have their own collection departments, but

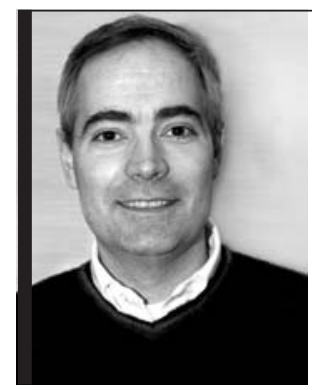

Bob Hunt is a senior economist in the Research Department of the Philadelphia Fed. This article is available free of charge at www. philadelphiafed. org/econ/br/index. html. they also farm out collection work to independent contractors (collection agencies). Federal, state, and local governments are also increasingly turning to such agencies to collect past-due loans, taxes, and other fees. More recently, creditors have begun selling off some of their poorly performing accounts to firms that specialize in collecting debts.

All in all, consumer debt collection has become a big business. In 2005, third-party debt collectors recovered $\$ 51$ billion in delinquent debts of all kinds, returning $\$ 39$ billion to their clients. ${ }^{1}$ They employ over 130,000 workers. Two-thirds of industry revenues are derived from collecting debts owed by consumers. For example, collection firms are actively seeking recoveries on $\$ 200$ billion in defaulted credit card debt. Today, debt collectors contact consumers over 1 billion times a year.

The effectiveness of the collection process has implications for the pricing and availability of consumer credit. ${ }^{2}$ The more difficult (or costly) it is to ensure that a loan is repaid, the higher will be the costs of borrowing, and less credit will generally be available. But certain collection tactics can be hard on consumers, and regulations at the federal and state levels reflect this concern. Despite these concerns, the collections industry has received remarkably little attention from economic scholars.

In this article, we will explore how creditors and their agents attempt to collect past-due consumer debt, focusing primarily on unsecured debt. ${ }^{3}$ For the most part, they rely on (not so gentle) persuasion, but they can also use legal remedies, such as garnishment of wages - a court-sanctioned deduction from a consumer's paycheck

${ }^{1}$ These statistics are from a recent survey by ACA International, a collections industry trade association.

${ }^{2}$ There are also effects for firms that do not receive immediate payment for all the goods or services they provide to their customers. For example, hospitals devote significant resources to collecting unpaid bills that are not covered by health insurance.

${ }^{3}$ For secured debts, the creditor at least has the hope of recovering the value of the underlying collateral, such as a car or home. For unsecured debts, this option is not available. 
that is used to pay an outstanding obligation. The effectiveness of these tactics, however, is limited by the fact that most consumers have the option to file for bankruptcy. Even outside of bankruptcy, consumers enjoy a variety of legal protections, but they may not be aware of them.

\section{CONSUMERS IN TROUBLE}

The total indebtedness of U.S. consumers in 2006 was about $\$ 13$ trillion. ${ }^{4}$ At any point in time, a significant number of consumers are behind in their debt payments. Between 1992 and 2005, on average, 4 million households were 120 or more days late on a debt payment (Figure 1). Lenders must eventually write some of these debts off their books because it is very unlikely they will ever be repaid in full. In 2006, for example, commercial banks alone charged off $\$ 29$ billion in credit card debt. ${ }^{5}$

Many distressed consumers enter into bankruptcy in order to discharge their debts (under Chapter 7) or to establish repayment plans under the aegis of a court-appointed trustee (under Chapter 13). Others participate in debt management plans arranged by a nonprofit credit counseling organization. ${ }^{6}$ But many consumers who are behind on their payments do not seek bankruptcy protection or, at least, not immediately. In fact, only one-half (or less) of credit card debt written off by banks is triggered directly by a consumer's filing for bankruptcy. ${ }^{?}$ Thus,

${ }^{4}$ About $\$ 9$ trillion of this amount represents mortgages. These numbers are from the Board of Governors' Flow of Funds (Z.1) report.

${ }^{5}$ These are the banks' gross losses. They do not reflect any recoveries from their collection efforts.

${ }^{6}$ For more information on the role credit counselors play, see my 2005 Business Review article.

\section{FIGURE 1}

\section{Consumers with Serious Delinquencies}

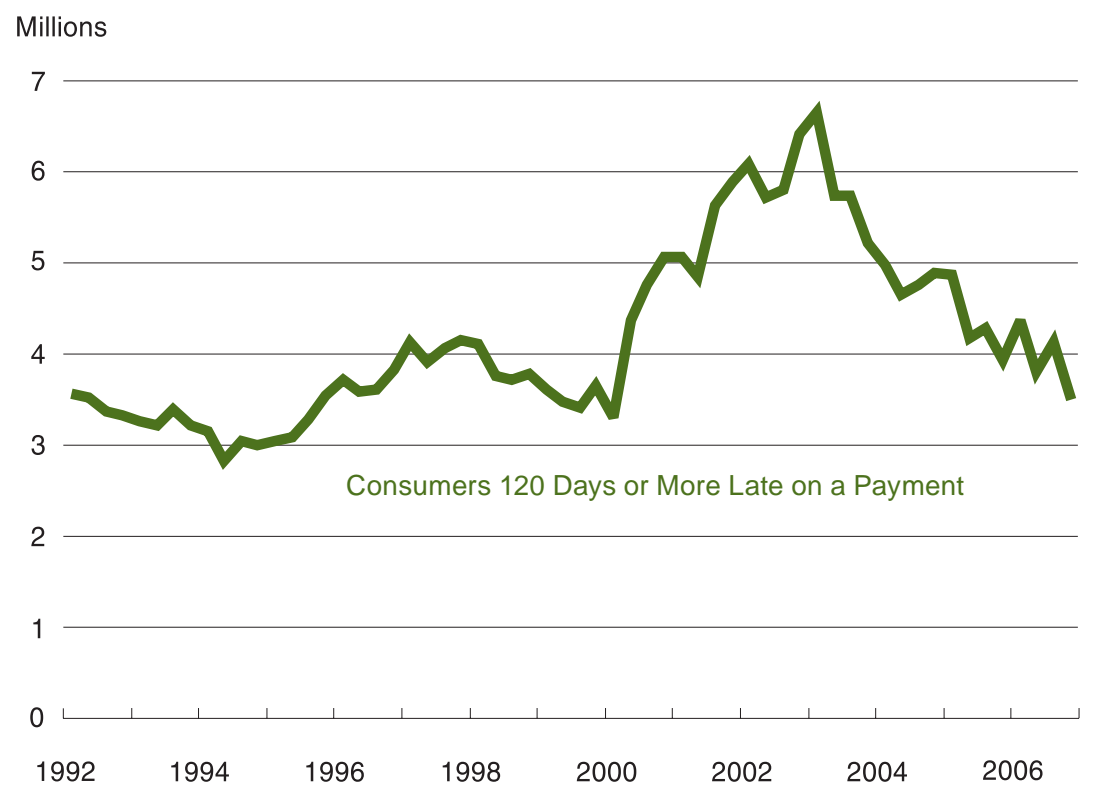

Source: TrenData and author's calculations

for most borrowers in arrears, there is a considerable period in which creditors and their agents seek to recover past-due debts using persuasion as well as the contractual and legal remedies available. For secured loans, this can mean foreclosure proceedings or repossession. For unsecured loans, the legal remedies include court judgments and garnishment of wages.

Since the relevant law varies considerably across states, the effectiveness of these remedies varies as well. State laws have also changed over time or, in a few cases, have been superseded by federal law. A number of economic studies, which are described later, have

${ }^{7}$ See the article by Michele White and the article by Lawrence Ausubel and Amanda Dawsey. found that these variations across states or time may be reflected in the pricing and availability of credit.

\section{WHAT IS THE DEBT COLLECTION INDUSTRY?}

Creditors allocate significant resources to in-house collection departments with the goal of bringing their customers current or minimizing the losses on debts that will go bad. In-house collections tend to focus on short-term delinquencies. If they are unable to collect these short-term delinquencies, these accounts are eventually sent to third-party collectors, who are compensated with a share of the recoveries they obtain. In the case of credit cards, for example, creditors typically hire third-party collectors at 180 days, the point at which the creditor charges off the balance. But creditors 
and other firms also sometimes rely on outside firms to assist in collections before chargeoff.

We do not know for certain why creditors choose to outsource a significant share of their collections work, but this pattern has existed for a very long time. ${ }^{8}$ It may simply be an example of the economics of specialization - firms focused exclusively on collections may somehow be better at it. They may enjoy superior technology, or they may be better at attracting employees who are especially adept at collections. A specialized firm may provide better incentives than a collections department in a larger organization that pursues many other objectives. Lenders may also worry more about risks to their reputation resulting from an aggressive collection strategy than a third-party firm specializing in the task. Finally, creditors usually place debts for collection only after their own efforts have failed. Perhaps another organization, with a different approach, will have more success.

In 2004, more than 450,000 people in the U.S. were employed as bill and account collectors. Collection agencies alone employed 94,000 debt collectors (21 percent of the total). Other leading employers include providers of financial services (20 percent), providers of health care (15 percent), and wholesalers and retailers (13 percent). ${ }^{9}$

In 2002, approximately 5,250 firms operated as third-party debt collectors. In total, they employed about 130,000 people and generated sales of

\footnotetext{
${ }^{8}$ William Krumbein's article dates the separation of lending and collections in the U.S. to 1880 , or even earlier.

${ }^{9}$ Issuers of credit cards alone employed nearly 18,000 collectors, 4 percent of the total. These data are from the Bureau of Labor Statistics' National Employment Matrix and Occupational Employment Statistics.
}

\section{FIGURE 2}

\section{Customers of Third-Party Debt Collectors (percent of revenues, 2002)}

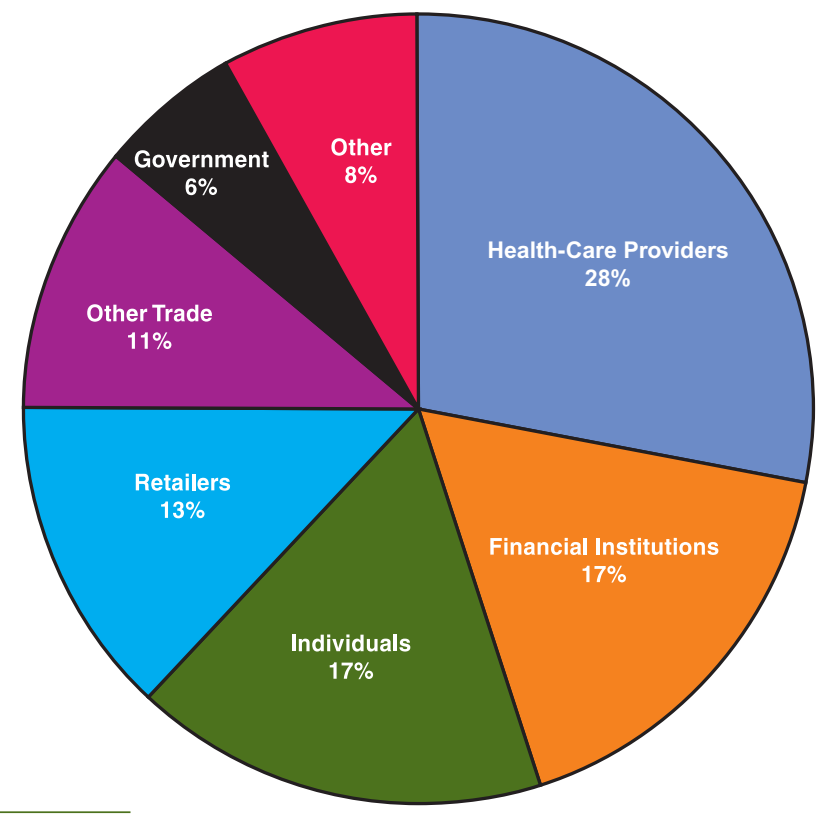

Source: Census Bureau and author's calculations

about $\$ 8.5$ billion ( $\$ 5.9$ billion from collecting on consumer debts). By 2005 , total revenues were $\$ 11.4$ billion. This is a growth industry. Between 1982 and 2002, total household debt adjusted for inflation doubled. Collection industry revenues (adjusted for inflation) increased 3.6 times and employment 2.5 times. $^{10}$

Third-party debt collectors serve a diverse set of customers (Figure 2). In 2002, health-care providers represented the most important group of customers, accounting for more than a quarter of all revenues. ${ }^{11}$ Financial institutions account for a smaller share, but, of course, many of these firms also maintain their own collections depart-

${ }^{10}$ These statistics are derived from the Census of Services and the Services Annual Survey. ments. Firms engaged in retail and wholesale trade account for about a quarter of the industry's revenues.

Statistics compiled by ACA International, an industry trade association, provide an interesting peek under the hood of the collections business. ${ }^{12}$ The median firm generated an impressive $\$ 402,000$ in collection revenues for each full-time collector it employed in 2005. This amount was generated by making relatively small collections (a median of \$68) on a very large number

${ }^{11}$ The significance of this industry is underscored by the fact that the majority of references to accounts in collection in consumer credit bureau files are associated with medical bills. The second leading category is utility bills. See the 2003 article by Robert Avery and his colleagues.

${ }^{12}$ These statistics are from ACA's 2005 Benchmarking Survey. 
of small accounts (with a median balance of about \$440). More than twothirds of this amount was returned to the creditor (the median commission was 28 percent). After deducting the firms' expenses (a median of $\$ 17$ per account), the median profit on an account was about $\$ 2$.

While the typical collection agency remains small, the industry has become more concentrated over time. The four largest firms took in 19 percent of industry receipts in 2002, compared with 11 percent in 1987. The largest firms generate at least $\$ 100$ million in revenue and employ more than 1,400 people each. A number of these firms are publicly held corporations. Since the early 1990s, these firms have increased their dominance of the industry (Figure 3). Given this rising concentration, we might expect the total number of active firms to decline. But in this industry, the number of firms and establishments has remained remarkably stable over time, suggesting significant ongoing entry into the collections business. In addition, many of the large collection firms outsource some of their work to smaller organizations.

One factor that may be contributing to the increasing scale of collection firms is the consolidation of consumer credit among the largest lenders in the country. For example, over the last decade, the share of credit card balances held by the four largest card-issuing banks has risen from just over 25 percent to over 85 percent. ${ }^{13}$ With every merger or sale of a credit card portfolio, there are fewer banks looking for collection services. Over time, these creditors have found it more convenient to work with fewer collection agencies, each collecting on a much larger number of accounts. A similar trend seems

${ }^{13}$ This statistic is the share of card debt among banks and thrifts that file Call Reports.

\section{FIGURE 3}

\section{Size Distribution of Collections Firms}

\section{Share of industry receipts}

(Percent)

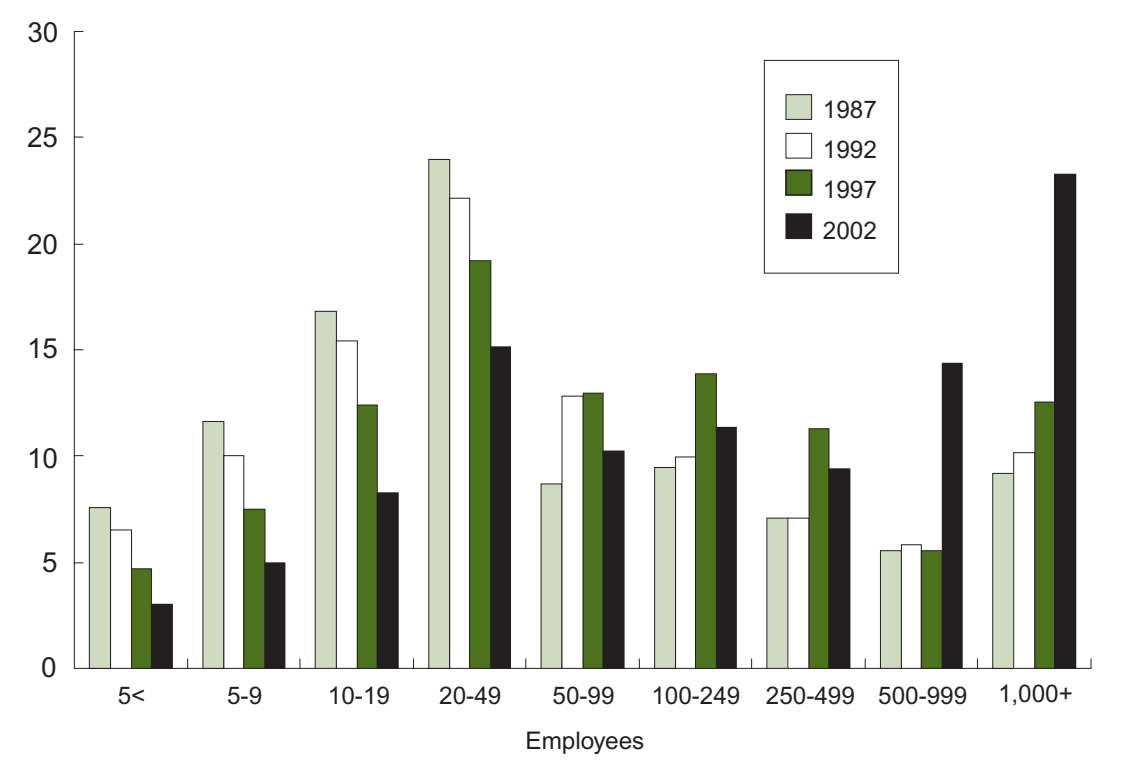

Source: Census Bureau and author's calculations

to be developing among law firms that specialize in collections-related legal services on behalf of creditors. ${ }^{14}$

Buying and Selling Bad Debt. Traditionally, third-party debt collectors have worked almost exclusively on a commission basis, essentially sharing any recoveries with the creditor. But this began to change during the 1990 s. Creditors began to sell their bad debt outright to firms, and this market has grown dramatically over time (Figure 4). Creditors also enter into agreements to sell a volume of bad debts to a debt buyer at specified intervals in the future. ${ }^{15}$

${ }^{14}$ See, for example, the 2005 article by Darren Waggoner and the 2006 article by Jane Adler.

${ }^{15}$ These are called forward flow contracts. See the article by Kate Fitzgerald.
The outright sale of nonperforming consumer loans was stimulated in part by regulators responding to the savings and loan crisis of the 1980s. As many thrifts failed, their assets were transferred to the Federal Deposit Insurance Corporation (FDIC). The FDIC and the Resolution Trust Corporation (RTC) began to sell off portfolios consisting of nonperforming loans, typically secured by commercial real estate. But the FDIC also found itself managing portfolios of nonperforming consumer loans, and these took up a disproportionate share of its managerial resources. So the FDIC sought out private buyers for those assets. ${ }^{16}$ Over time, these agencies were able to devel-

${ }^{16}$ See Chapter 12 of the FDIC's book Managing the Crisis. 


\section{FIGURE 4}

\section{Sales of Bad Consumer Debt (face value)}

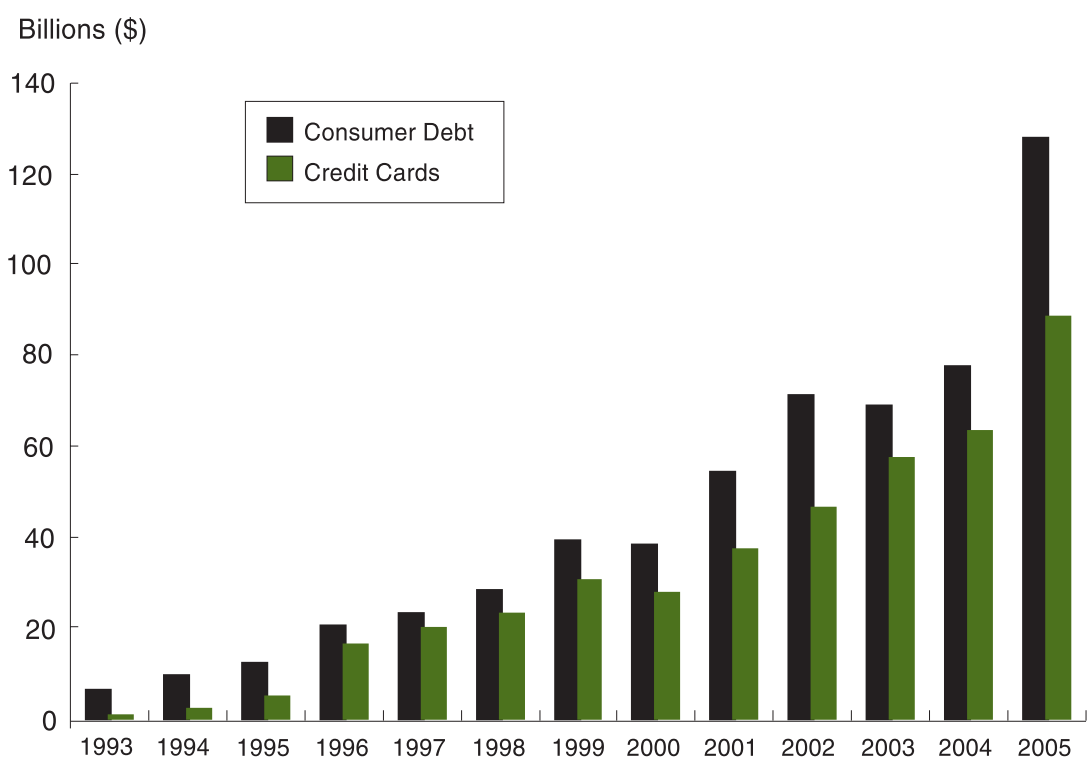

Source: The Nilson Report

op a significant market for small loans. Between 1986 and 1994 the FDIC sold some $\$ 20$ billion (face value) of these portfolios.

A little more than a decade later, in 2005, $\$ 128$ billion (face value) in nonperforming consumer debt in the U.S. was sold. Two-thirds of this amount ( $\$ 88$ billion) was defaulted credit card debt. Most of the bad credit card loans ( $\$ 65$ billion in face value) were sold directly by card issuers; the remainder was debt exchanged between different debt buyers. ${ }^{17}$ Card issuers received about $\$ 3$ billion, roughly 4.5 cents for each dollar of face value, for the defaulted loans they sold in

\footnotetext{
${ }^{17} \mathrm{Bad}$ debt is often sold more than once, typically at ever lower prices, as different buyers try to succeed where their peers have failed.
} bad credit card loans purchased..$^{18} \mathrm{~A}$ number of the largest debt buyers are publicly held firms, and these alone account for at least one-fifth of debt a number of these firms issue securigraph are from The Nilson Report, Nos. 806, ties backed by collections on the debt they have acquired. The growth of this market has also been stimulated by a significant inflow of capital from Wall Street. ${ }^{19}$ This, in turn, has stimulated demand for defaulted credit card portfolios, driving up prices and inducing debt buyers to seek out alternative portfolios, such as debts owed to hospitals. In a similar cycle, during the 1990s, some large purchasers of debt were unable to collect enough from the accounts to justify the prices they paid for the debt. They eventually failed, and competitors absorbed their assets. $^{20}$

Changes in Technology. The keys to collecting bad debt have not changed over the last 30 years: (1) locating the debtors and (2) efficiently distinguishing between those consumers who can't pay because they lack the resources to do so and those who won't pay even if they have the resources to make at least a partial payment. What has changed is the technology available to collection workers.

Thirty years ago, collectors worked primarily with paper records, typewriters, and telephones. The advent of affordable long-distance services (WATS lines) in the 1970s represented a major advance, permitting firms to collect accounts over greater distances at lower cost. Another advance was the automated dialer: A computer dials the numbers of delinquent consumers more rapidly than humans can and routes the calls that are answered to collectors organized into a call center. ${ }^{21}$ This significantly purchases. To enhance their resources,

${ }^{18}$ The statistics in this and the preceding para835 , and 857 .
${ }^{19}$ In 2004-05 collection firms raised $\$ 500$ million from equity issues alone. See the article by Joe Chumbler.

${ }^{20}$ See the 2005 article by Jane Adler and the 2006 article by Darren Waggoner.

${ }^{21}$ The Nilson Report No. 558 (1993) identifies Don Thorne as the inventor of this technology, which emerged around 1973. 
increases the number of consumer contacts a collector can make in an eight-hour shift.

Over time, these systems have become more and more sophisticated (the latest generation machines are called predicative dialers). Computers determine the number of calls to make based on the time of day, the number of collectors logged on to the system, and variations in their average time speaking with consumers.

These calculations are more accurate when more collectors are used and, combined with the high fixed costs of such systems, may explain part of the increasing scale of collection agencies. The latest systems are also integrated with the agency's consumer account systems and other programs. Today, a number of the largest agencies have call centers located in other countries and are experimenting with Internet technology that permits collectors to work from home. ${ }^{22}$

Three decades ago, a leading textbook described the collections problem in the following terms: "Collection work would be easier and the results better if there were some magic way in which each account could be immediately and accurately classified as to the reason for nonpayment and the collection method which would be most effective with that particular debtor. Sorting devices to perform such miracles unfortunately are not yet available."23

Since then, the industry has worked hard to develop better sorting technologies. Collection records are now computerized. Advances in information technology have made the process of skip tracing - locating a current address or phone number of

\footnotetext{
${ }^{22}$ See the 2003 article by Jane Adler.

${ }^{23}$ See p. 371 of the book by Robert Cole.
}

a consumer - more efficient. Techniques developed to quantify the risk of borrower default (credit scoring) are now being applied to evaluating the prospects for successful collections of individual accounts and the pricing of entire portfolios. ${ }^{24}$ Given that collectors are generally able to obtain payments on only a small fraction of their erable resources and investments in technology to separate the two groups based on the information they can collect (see the preceding section). Second, they apply additional pressure on consumers, essentially increasing the implicit cost of not repaying one's debt. This may induce those who won't pay to change their minds. But this also

\section{To be effective, collectors must be able to distinguish consumers who can't pay from those who won't pay even though they have the resources to do so.}

accounts, it is extremely important to know how to allocate collection resources across accounts. Among the accounts that do end up being paid, most are the result of an improvement in the borrower's financial condition, which can often take years. Thus, the ability to locate a delinquent borrower and monitor changes in his or her financial condition three or five years after the initial default can be extremely valuable.

\section{REGULATING THE DEBT COLLECTION PROCESS}

To be effective, collectors must be able to distinguish consumers who can't pay from those who won't pay even though they have the resources to do so. The problem that collectors face, however, is that consumers in these two categories look very much alike because those who won't pay have an incentive to present themselves as consumers who can't.

Collectors respond to this problem in two ways. First, they devote consid-

${ }^{24}$ See the article by Amita Chin and Hiren Kotak, the article by Joanne Cleaver, and the one by Peter Lucas. imposes additional distress on those who really cannot pay. ${ }^{25}$

There is a related problem: Outside of bankruptcy, creditors have an incentive to race for the consumer's limited assets or income. When it becomes clear that a consumer is having difficulty paying his or her debts, creditors become concerned about their priority: What is the order in which creditors will be repaid from the consumer's assets or a garnishment of his or her wages? Knowing that other creditors are doing the same, each creditor has an incentive to seek immediate repayment of its debt even if it comes at the expense of other creditors or induces a sale of the consumer's assets at fire-sale prices. ${ }^{26}$ Under these circumstances, creditors and their agents have a natural incentive to be aggressive in their collection efforts at the expense of both the consumer and

${ }^{25}$ For a thoughtful discussion of this problem, see the article by Arthur Leff. For real world examples, see the 1977 and 1992 congressional hearings on the Fair Debt Collection Practices Act.

${ }^{26}$ This phenomenon is explored in the book by Thomas Jackson and the one by Winton Williams. 
his or her other creditors.

These problems can be mitigated.

With the assistance of a nonprofit credit counselor, consumers can work out a debt management plan with their creditors. Alternatively, consumers can file for bankruptcy. ${ }^{27}$ The immediate effect of a bankruptcy filing is that it forces creditors to cease collection efforts. The court then works out a plan for liquidating the consumer's nonexempt assets (Chapter 7) to pay the creditors or, alternatively, a plan for using the consumer's future income to repay some of his or her debts over time (Chapter 13). In either case, unsecured creditors are likely to lose some, perhaps all, of the principal loaned. The consumer will carry a bankruptcy flag on his or her credit report for 10 years.

Unfortunately, debt management plans are not always successful. And, as noted above, consumers often do not immediately file for bankruptcy — sometimes because they can't. ${ }^{28}$ Thus, a rationale for government regulation of collection activities directed at consumers follows from these arguments: (1) there is excessive racing in collections by unsecured creditors, (2) creditors cannot easily distinguish between those who can't pay and those who simply won't pay, and (3) consumers are either unwilling or unable to file for bankruptcy.

First Steps Toward a Federal Role. Until the end of the 1960s, the regulation of consumer debt collection outside of bankruptcy was done

\footnotetext{
${ }^{27}$ For a discussion of the purposes and design of consumer bankruptcy law, see the Business Review article by Loretta Mester. The federal bankruptcy law was amended in 2005. For details, see the First Quarter 2005 issue of the Federal Reserve Bank of Philadelphia's Banking Legislation and Policy.

${ }^{28}$ Under U.S. law, consumers can obtain a discharge of their debts under Chapter 7 only once in eight years. There are also limitations on the frequency of discharges under Chapter 13.
}

almost exclusively at the state or local level. But this soon began to change, perhaps because of the development of the credit card market and, more generally, the gradual evolution toward a national market for consumer credit. ${ }^{29}$

One of the first assertions of a federal role occurred in 1968 when the Federal Trade Commission (FTC) published guidelines describing explicit collection practices it deemed to be unfair or deceptive trade practices and

\section{Until the end of the} 1960s, the regulation of consumer debt collection outside of bankruptcy was done almost exclusively at the state or local level.

therefore subject to prosecution. In the 20 years ending in 1977, the FTC filed cases against approximately 10 collection agencies a year.

In 1970, a federal ceiling on wages subject to garnishment (at most 25 percent of take-home pay) went into effect. ${ }^{30}$ The Fair Credit Reporting Act of 1970 limited how long adverse repayment behavior could be included in a credit report and provided a process for disputing inaccurate information contained in a consumer's credit report. ${ }^{31}$ In 1974, Congress passed the Fair Credit Billing Act — another

${ }^{29}$ For a description of the evolution of the credit card market, see the book by Joseph Nocera and the one by David Evans and Richard Schmalensee. In recent years, a similar process has occurred for residential mortgages.

${ }^{30}$ Title II of the Consumer Credit Protection Act of 1969 (Public Law 90-321, 15 USC 1601). At the time of enactment, this protection was more generous than what was available under the laws of about 25 states. reaction to the rapid and sometimes clumsy growth of the market for general-purpose credit cards. ${ }^{32}$ This law establishes a process for consumers who have disputed billing errors on their credit card accounts. Until the billing error is resolved, consumers do not have to pay the disputed amount (or interest on that amount), and the lender is precluded from attempting to collect on it.

\section{FAIR DEBT COLLECTION PRAC. TICES ACT (FDCPA) OF 1977}

This law establishes a national floor for consumer protections from third-party debt collectors. The act's general thrust is to prohibit the harassment of consumers and the use of collection practices deemed to be unfair. (See Fair Debt Collection Practices Act.)

The Federal Trade Commission (FTC) primarily enforces the act, but authority is shared with the federal financial regulators and several other federal agencies. An important remedy is the right of consumers, either individually or jointly in a class action, to sue collectors for (limited) damages arising from violations of the act, plus reasonable attorney's fees. Thus, enforcement need not depend on the resources or interest of public agencies.

But there are a number of important limitations to the protections provided under the act. First, debt collectors are not liable for damages if they can show that the offense was unintentional and that they maintain policies and procedures designed to avoid such violations. In practice, the courts have interpreted this exception relatively narrowly, so there have been many damage awards over the years.

\footnotetext{
${ }^{31}$ Public Law No. 91-508, 15 USC 1681 et seq. I review this legislation in my 2002 article in the Business Review.

${ }^{32}$ Public Law 93-495, 15 USC 1666 et seq.
} 


\section{The Fair Debt Collection Practices Act ${ }^{\mathrm{a}}$}

hat debts are covered? The act applies to personal, family, or household debts.

Who is a debt collector? The act defines a debt collector as any person who regularly collects debts owed to others. This includes attorneys who collect debts on behalf of others on a regular basis.

The act does not apply to creditors (or their affiliates) collecting debts exclusively owed to them. The exclusion also applies to the collection of debts acquired from another creditor, so long as the debt was not in default at the time of the sale. But the act applies to a creditor collecting its own debt using a different name, thus giving the impression that it is a third-party collector.

The act does not apply to process servers or nonprofit organizations providing bona fide consumer credit counseling services and administering debt management plans on behalf of the consumer.

May a debt collector contact anyone else about a consumer's debt? If the consumer has an attorney, the debt collector may contact only the attorney, unless the consumer otherwise consents or his or her attorney does not respond to the collector's calls or letters.

If the consumer does not have an attorney, a collector may contact other people, but only to obtain information about the location of the consumer (for example, an address or a phone number). Collectors usually are prohibited from contacting third parties more than once. In such communications, collectors must identify themselves but may disclose the name of his or her employer only if specifically requested. The collector may not disclose that the consumer owes a debt.

What information about the debt must be provided to the consumer? Upon initial contact with a consumer, the collector must indicate it is attempting to collect a debt and that any information obtained will be used for that purpose. Within five days of the initial contact, the collector must send the consumer a written notice describing the exact amount owed, to whom it is owed, and that the consumer can dispute this information if he or she believes it is inaccurate. The consumer has 30 days to dispute this information (in writing). If the consumer disputes an alleged debt, the collector must cease collection efforts and verify the accuracy of the information. The collector may resume its efforts once it has verified the information and mailed proof of the debt to the consumer.

When may a collector contact a consumer? Collectors may not contact consumers at unusual times or at an inconvenient place, without prior consent. Hours between 8 a.m. and 9 p.m. are presumed to be convenient times. A collector may not contact a consumer at his or her place of employment if it has reason to know that such communications are prohibited by the employer.

How can a consumer stop the collector from contacting him or her? A consumer (his or her spouse or a parent of a minor) can terminate a collector's efforts to contact him by sending the collector a letter to that effect. Thereafter, a collector may communicate with the consumer only to indicate that (1) the collector is ceasing further collection efforts or (2) it (or the creditor) may or will take a specific action against the consumer (such as a garnishment of wages).

\section{What types of debt collection practices are pro-} hibited? Debt collectors may not harass, oppress, or abuse a consumer or any third parties they contact. For example, collectors may not use threats of violence or harm, publish a list of consumers who refuse to pay their debts (except to a credit bureau), use obscene or profane language, or repeatedly use the telephone to annoy someone. A collector may not circulate to any person credit information it knows, or should know, is false. This includes failing to communicate that a debt is being disputed by the consumer.

Debt collectors may not use any false representation or deceptive means to collect or attempt to collect any

a Public Law No.95-109 (1977). The law in its current form may be found in title 15, section 1692 of the U.S. Code. For more information see the FTC's website: www.ftc.gov. 
debt or to obtain information concerning a consumer. For example, they may not misrepresent the name of the collection firm, the amount or legal status of a debt, or the legal status of forms sent to the consumer. They may not falsely imply that they are attorneys, government representatives, or employees of a credit bureau or that the consumer has committed a crime. A collector may not threaten to take an action it (or the creditor) does not intend to take or that is illegal.

A debt collector may not use unfair or unconscionable means to collect a debt. For example, a collector may not collect any amount (including any interest, fee, charge, or expense) that is not expressly authorized by the agreement creating the debt or permitted by law. Collectors may not deposit a post-dated check prematurely. Debt collectors may not communicate with a consumer about a debt via postcard. In letters sent to consumers, collectors may print only their address on the outside of the envelope. ${ }^{\mathrm{b}}$

In what jurisdiction may a debt collector sue a consumer? If the loan is secured by real property (a house or land), the collector must file in the jurisdiction where the property is located. Otherwise, the collector must file either where the consumer signed the contract or where the consumer currently resides.

What remedies are available to consumers? A consumer can sue a debt collector for violations of the act in state or federal court. The statute of limitations runs for one year from the date of the violation. Consumers may recover actual damages and reasonable attorneys' fees. The court may award up to $\$ 1,000$ for additional damages for individual suits.

The act also allows for class action suits against debt collectors. In that case damages are capped at the minimum of $\$ 500,000$ or 1 percent of the collector's net worth. In determining the damages to award, the court will consider the frequency and persistence of noncompliance, its nature, and whether it was intentional.

A debt collector is not liable for damages if it can show the violation was not intentional and that it used procedures reasonably designed to avoid such violations. If a court finds that a suit was brought in bad faith, to harass a debt collector, the court may require the plaintiff to compensate the defendant for the (reasonable) attorney's fees incurred.

What federal agencies enforce the act? Most debt collectors may be sued for violations by the Federal Trade Commission, which may seek civil penalties and injunctions. Other federal agencies are responsible for enforcing the act among the firms they supervise.

\section{What about state laws regulating debt collection?}

The act sets a floor of consumer protection from debt collectors. States are free to enact protections that are stronger than those provided in the federal law.

\footnotetext{
${ }^{\mathrm{b}}$ The envelope can include the name of the firm if it does not suggest that it is in the debt collection business. This restriction also applies to written communications to third parties.
}

${ }^{\mathrm{c}}$ These include the federal regulators of financial institutions, common carriers, and airlines.

More important, the act applies only to firms collecting debts on behalf of others - that is, to third-party debt collectors. The act does not apply to firms collecting debts owed to them as long as they use the firm's name in the collection process. Thus, most creditors are not considered debt collectors when they contact their customers about a delinquency or a default.

Why 1977? Given the long tradition of regulating collection practices at lower levels of government, it is interesting to ask why Congress decided to act in 1977. A number of factors seem important. First, there was con- siderable interest, and some research, on consumers having difficulties managing their debt and filing for bankruptcy. Some of the research resulted from studies commissioned by the National Commission on Consumer Finance, which Congress established when it enacted the Truth in Lend- 
ing Act in $1968 .{ }^{33}$ Second, many in Congress believed that the protections provided by state law were inadequate. At that time, 13 states had no laws that applied to debt collectors, and the laws in another 16 were considered too weak. ${ }^{34}$ Finally, advances in telecommunications had reduced the cost of long-distance business calls, making it economical for firms located in one state to collect debts owed by consumers in other states. Few states had the legal remedies or sufficient resources to discipline collection firms located out of state.

Nevertheless, federal legislation in this area was controversial. Some viewed the act as an attempt to protect deadbeats that would reduce the efficiency of the credit market. Others argued it was another instance of federal intrusion into an area of policy that traditionally belonged to the states. The act passed by only one vote in the House of Representatives.

\section{Protecting Unsophisticated}

Consumers. Shortly after the FDCPA was enacted, the courts developed the "least sophisticated consumer" standard to evaluate alleged violations of the FDCPA. ${ }^{35}$ This is rather different from the approach used under many other federal consumer protection laws that apply to financial services. For example, laws such as the Truth in Lending Act or the Real Estate Settlement Procedures Act require that lenders disclose a good deal of information, and it is assumed the consumer is sufficiently sophisticated to make use of the information. In ambiguous cases, the

\footnotetext{
${ }^{33}$ See also the study by David Caplovitz and another by David Stanley and Marjorie Girth, which influenced the drafting of the Bankruptcy Act of 1978.

${ }^{34}$ See Senate Report 95-382.

${ }^{35}$ Some courts use a different standard, referring to an "unsophisticated consumer," but there is little practical difference between the two.
}

consumer must demonstrate that the disclosures were somehow inadequate and this resulted in a loss to the consumer. In contrast, under the FDCPA, the question before the court may not be whether the plaintiff was actually deceived but rather whether the debt collector's action would have confused "the least sophisticated consumer." 36

Why Exclude Creditors? The rationale for the distinction between third-party and first-party collectors is somewhat convoluted. On the one hand, if the act had been written to include creditors, it is likely the bill

\section{The FDCPA acts as a floor for consumer protections rather than as a ceiling.}

would not have passed. On the other hand, a number of participants in the congressional hearings on the bill argued that the protections were primarily needed to address the activities of third-party collectors. The FTC took the position that it was easier for regulators to discipline financial institutions than to discipline debt collectors. It argued that barriers to entry into the collections business were so low that actions taken against existing firms did little to deter the behavior of new firms entering the business.

Others argued that financial institutions were already more heavily regulated, and the limited data available at the time suggested that most complaints were about the conduct of the third-party collectors. ${ }^{37}$ Also, at that time, consumers borrowed almost

\footnotetext{
${ }^{36}$ This reasoning is contained in the 1991 case Beattie v. D.M. Collections 754 F. Supp. 383.

${ }^{37}$ But the latter claim was disputed at the time by ACA International (the Association of Cred it and Collection Professionals) and others.
}

exclusively from lenders located in their state, so it was felt that state laws would be more effective in disciplining creditors than debt collectors located in other states. ${ }^{38} \mathrm{~A}$ final bit of reasoning that was influential at the time was the idea that firms collecting their own debts were also collecting from their own customers and would be less willing to damage these relationships, or their reputation among potential customers, by using aggressive collection tactics. ${ }^{39}$

Changes Since 1977. There have been relatively few changes to the act since 1977. The most significant change occurred in 1986 when Congress eliminated an exception to the definition of debt collector for lawyers collecting debts as an attorney on behalf of a client. ${ }^{40}$

Unlike many other areas of federal regulation of financial activities, the FDCPA acts as a floor for consumer protections rather than as a ceiling. Thus, states are free to enact protections that are more extensive than the FDCPA's and to apply them to a broader variety of collections activity. In the nearly 30 years since the enactment of the FDCPA, many states have adopted more extensive regulation of debt collection practices. Today, more than 40 states have laws that apply to third-party debt collectors, and more than 30 states have laws that can be applied to creditors collecting their own debts. ${ }^{41}$ Of course, there is still

\footnotetext{
${ }^{38}$ Of course, in just a few years it was common for consumers to use a credit card issued by a bank located elsewhere, primarily in Delaware or South Dakota.

${ }^{39}$ Richard Peterson's 1986 study provides some evidence that creditors are less willing to use remedies consumers dislike the most - that is, unless the remedy is especially effective for obtaining repayment.

${ }^{40}$ Public Law 99-361, 100 Stat. 768

${ }^{41}$ For more information on state debt collection laws, see the article by Elizabeth Bohn and Ari Gerstin and the book by Robert Hobbs.
} 
considerable variation in the extent of protections offered at the state level.

Finally, in addition to regulation of the collections industry, contractual remedies available to creditors have also seen changes. After a decade of deliberations, the FTC issued its credit practices rule in 1985. Among other things, this rule made unenforceable a number of remedies lenders often included in their consumer credit contracts. ${ }^{42}$ The FTC ban includes waivers that permit creditors to automatically obtain a judgment against the consumer in court or waivers of asset exemptions provided under state bankruptcy law. ${ }^{43}$ The rule prohibits creditors from deducting payments from the employee's paycheck without his or her permission and without first obtaining a court order. The rule also prevents creditors from obtaining a security interest in the consumer's other household goods as collateral for a loan.

A number of studies on the effects of these contractual restrictions have produced conflicting results. ${ }^{44}$ Economists often measure the effects of legal changes by examining changes in demand and supply. On the one hand, reducing the options available to lenders may reduce the likelihood of repayment. This might induce lenders to charge higher interest rates and offer less credit than before. In other words, the supply of credit might fall. As an example, one study finds that, all else equal, mortgage loans are 3 percent to 7 percent smaller in states with a more lengthy and costly foreclosure

\footnotetext{
${ }^{42}$ See 16 CFR Part 444. These restrictions were applied to banks under Regulation AA, issued by the Board of Governors of the Federal Reserve System. A number of these restrictions were recommended in the 1972 report of the National Commission on Consumer Finance.

${ }^{43}$ In bankruptcy, exempted assets are protected from creditors. These exemptions are sometimes important outside of bankruptcy, too.

${ }^{44}$ For a recent review of this literature, see the article by Richard Hynes and Eric Posner.
}

process. ${ }^{45}$ Another study found that interest rates on individual personal loans were higher (and loan amounts were smaller) in states where a smaller share of take-home pay was subject to garnishment. ${ }^{46}$

On the other hand, consumers might be unwilling to borrow when creditors have the option to use remedies they really don't like. In that case, restricting some remedies could increase the demand for credit so long as consumers are willing to pay for the protection. One study found that, all

\section{CONCLUSION}

In an article published in 1924, William Krumbein concluded that "the large number of delinquent claims each year assigned to collection agencies indicate the need for some form of institution as a means of raising capital through bad debts, or as a means of reducing the enormous losses from this source. The question at issue, then, in considering the present-day collection agencies, is not whether they can actually justify their existence on economic grounds, but whether they perform

\section{Today, more than 40 states have laws that apply to third-party debt collectors, and more than 30 states have laws that can be applied to creditors collecting their own debts.}

else equal, consumers were more likely to borrow, and borrow more, in states where less take-home pay was subject to garnishment, suggesting that at least some consumers were indeed willing to pay the additional cost resulting from the restriction. ${ }^{47}$

Another interesting finding is that even in places where these remedies are available, creditors invoke them infrequently. One interpretation is that creditors are unwilling to use remedies that would damage their reputation with existing or potential customers. Another interpretation is that the remedies were effective in motivating repayment where it was feasible and, thus, did not need to be used very often. $^{48}$

${ }^{45}$ See the 2005 article by Karen Pence.

${ }^{46}$ See the 1983 article by James Barth and his colleagues and the 1973 study by Douglas Greer.

${ }^{47}$ See the 1990 article by Daniel Villegas. Note that Villegas examined the nonmortgage borrowing of consumers, while the article by Barth and his colleagues examined the characteristics of individual loans made by finance companies. These differences may explain why they obtained different results.

${ }^{48}$ See the article by Robert Scott. their function in such a manner as will net the largest possible benefit to society as a whole." The answer, according to Krumbein, depended on the kinds of firms that undertook the collections and how the original lenders held them accountable for their tactics.

That answer remains largely true today, subject to some qualifications. First, some collection firms are now also the owners of the defaulted debt they seek to recover. Second, the government plays a more active role in policing collections activity than it did prior to 1970.

So it is distressing to see a significant increase in consumer complaints about collections activity in recent years (Figure 5). In comparison, the FTC reported receiving about 5,000 complaints about debt collectors in the years before the passage of the FDCPA, followed by a decline to about 2,000 a year in 1983. By 1990, complaints had fallen to about 1,000 a year before doubling by 1992 — another period of recession. ${ }^{49}$

${ }^{49}$ See the 1984 testimony of Ann Price Fortney and the 1992 testimony of David Medine. 


\section{FIGURE 5}

\section{Complaints to the Federal Trade Commission}

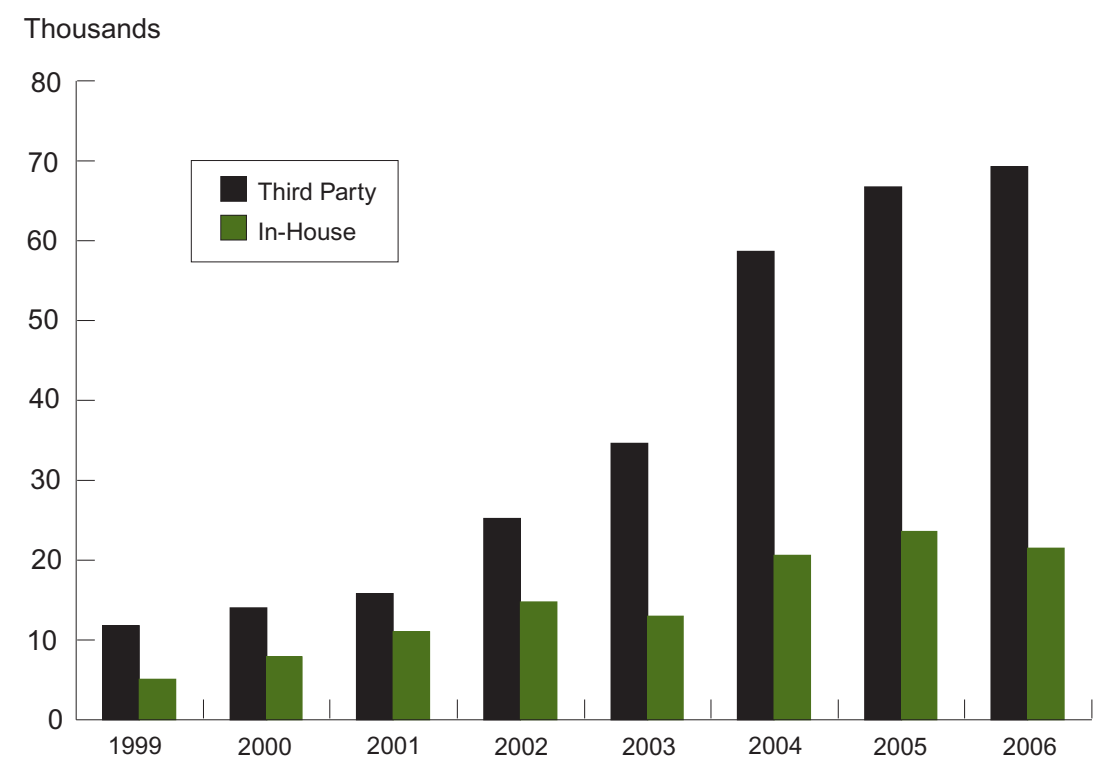

Source: Federal Trade Commission and author's calculations.

The recent increase in complaints may reflect a number of factors, for example, the recent recession and the resulting increase in delinquent debt flowing to collection departments or the increased ease with which consumers can register complaints via the Internet. At this point, we can't be certain why there are now so many complaints and why they seem to be increasing.

Despite the prevalence of consumer collection activity, there is relatively little economic research on the topic, and much of what there is dates to the initial era of federal consumer protec- tion regulation that began around $1970 . .^{50}$ Economists have tended to focus on the related question of the effects of the bankruptcy system, leaving unexplored the question of what distressed consumers, and their creditors, do outside of bankruptcy. While there is a rationale for regulating the consumer collections process, we know little about the effects of these regulations. Are they too onerous? Are they too weak? How have creditors, debt collectors, and consumers responded?

In the three decades since the FDCPA was passed, consumer credit and the resulting collections process have changed considerably. Debt collectors are now big business, some trading on Wall Street. Lenders are comfortable selling off their bad debts, and a relatively deep market for these assets now exists. The IRS is experimenting with using private firms to collect some of the $\$ 250$ billion in delinquent taxes outstanding. The credit card market is now mature and relatively concentrated. Consumer bankruptcy law has recently been changed. It would seem this area is ripe for a new generation of research.

${ }^{50}$ One exception is the forthcoming article by Richard Hynes. 


\section{REFERENCES}

ACA International. 2005 Benchmarking and Agency Operations Survey. Minneapolis, MN: ACA International, 2005.

ACA International. Value of Third Party Debt Collection to the U.S. Economy: Survey and Analysis. Minneapolis, MN: ACA International, 2006.

Adler, Jane. "Law Firms Balloon," Cards and Payments, 19 (April 2006), pp. 48-51.

Adler, Jane. "Alternative Assets," Credit and Collections World, 18 (February 2005).

Adler, Jane. "Offshore Collections," Collections and Credit Risk, 8 (July 2003), pp. 24-30.

Ausubel, Lawrence M., and Amanda Dawsey. "Informal Bankruptcy," mimeo, University of North Carolina, Greensboro (2003).

Avery, Robert B., Raphael W. Bostic, Paul S. Calem, and Glenn B. Canner. "An Overview of Consumer Data and Credit Reporting," Federal Reserve Bulletin (February 2003), pp. 47-73.

Barth, James R., Padma Gotur, Neela Manage, and Anthony M. J. Yezer. "The Effect of Government Regulations on Personal Loan Markets: A Tobit Estimation of a Microeconomic Model," Journal of Finance, 38 (September 1983), pp. 1233. 51.

Barth, James R., Joseph J. Cordes, and Anthony M. J. Yezer, "Benefits and Costs of Legal Restrictions on Personal Loan Markets," Journal of Law and Economics, 29 (October 1986), pp. 357-80.

Bohn, Elizabeth M., and Ari H. Gerstin. "FDCPA Traps for the Unwary Nationwide Lender, Loan Servicer, and Debt Collector: Part II," American Bankruptcy Institute Journal, 24 (May 2005).
Bureau of the Census. Census of Service Industries. Washington: U.S. Government Printing Office, various years.

Bureau of the Census. Current Business Reports: Service Annual Survey. Washington: U.S. Government Printing Office, various years.

Caplovitz, David. Consumers in Trouble: A Study of Debtors in Default. New York: The Free Press, 1974.

Chin, Amita Goyal, and Hiren Kotak. "Improving Debt Collection Processes Using Rule-based Decision Engines: A Case Study of Capital One," International Journal of Information Management, 26 (2006), pp. 81-88.

Chumbler, Joe. "Debt Purchasing Outlook for 2005," The Paper (July/August 2005).

Cleaver, Joanne. "Collections Calls Go High Tech," Credit Card Management, 15 (July 2002), pp. 48-51.

Cole, Robert H. Consumer and Commercial Credit Management, $5^{\text {th }}$ ed. Homewood, IL: Richard D. Irwin, Inc., 1976.

Consumer Credit in the United States: Report of the National Commission on Consumer Finance. Washington: U.S. Government Printing Office, 1972.

Evans, David S., and Richard Schmalensee. Paying with Plastic: The Digital Revolution in Buying and Borrowing. Cambridge, MA: MIT Press, 1999.

"Experian Software Evaluates Debt Portfolios," Cardline, 6 (February 2006).

Fair Debt Collection Practices Act. Hearing before the House Subcommittee on Consumer Affairs and Coinage of the Committee on Banking, Finance, and Urban Affairs, $102^{\text {nd }}$ Congress, $2^{\text {nd }}$ Session (September 10, 1992).
Fair Debt Collection Practices Act. Hearing before the House Subcommittee on Consumer Affairs of the Committee on Banking, Finance, and Urban Affairs, 95 ${ }^{\text {th }}$ Congress, $1^{\text {st }}$ Session (March 8-10, 1977).

Fair Debt Collection Practices Act. Hearing before the House Subcommittee on Consumer Affairs of the Committee on Banking, Finance, and Urban Affairs, 95 ${ }^{\text {th }}$ Congress, $1^{\text {st }}$ Session (May 12-13, 1977).

Federal Deposit Insurance Corporation. Managing the Crisis: The FDIC and RTC Experience, 1980-1994, Vol. 1. Washington: FDIC, 1998.

Federal Trade Commission. Annual Report: Fair Debt Collection Practices Act. Washington: Federal Trade Commission, various years.

Fitzgerald, Kate. "Going with the Flow," Credit Card Management, 12 (October 1999), pp. 65-68.

Flow of Funds Accounts of the United States. Washington: Board of Governors of the Federal Reserve System, 2006.

Fortney, Ann Price. Prepared Statement in Oversight Hearing on the Fair Debt Collection Practices Act. Hearing before the House Subcommittee on Consumer Affairs and Coinage of the Committee on Banking, Finance, and Urban Affairs, $98^{\text {th }}$ Congress, $2^{\text {nd }}$ Session (January 31, 1984).

Greer, Douglas F. "Creditor Remedies and Contract Provisions: An Economic and Legal Analysis of Consumer Credit Collection," in National Commission on Consumer Finance, Technical Studies, Vol. 5, Washington: U.S. Government Printing Office, 1973.

Hobbs, Robert J. Fair Debt Collection, $5^{\text {th }}$ Edition. Boston: National Consumer Law Center, 2004. 


\section{REFERENCES}

Hunt, Robert M. "Whither Consumer Credit Counseling?," Federal Reserve Bank of Philadelphia Business Review (Fourth Quarter 2005).

Hunt, Robert M. "What's in the File? The Economics and Law of Consumer Credit Bureaus," Federal Reserve Bank of Philadelphia Business Review (Second Quarter 2002).

Hynes, Richard. "Broke but Not Bankrupt: The View from the State Courts," Florida Law Review (forthcoming).

Hynes, Richard, and Eric A. Posner. "The Law and Economics of Consumer Finance," American Law and Economics Review, 4 (2002), pp. 168-207.

Jackson, Thomas H. The Logic and Limits of Bankruptcy Law. Washington: Beard Books, 1986.

Krumbein, William C. "Collection Agencies," University Journal of Business, 3 (1924), pp. 48-67.

Leff, Arthur A. "Injury, Ignorance and Spite - The Dynamics of Coercive Collection," Yale Law Journal, 80 (1970), pp. 1-46.

Lucas, Peter. "Letting the Numbers Tell the Story," Collections and Credit Risk, 11 (2006), pp. 37-39.
Medine, David. Prepared Statement in The Fair Debt Collection Practices Act. Hearing before the House Subcommittee on Consumer Affairs and Coinage of the Committee on Banking, Finance, and Urban Affairs, $102^{\text {nd }}$ Congress, $2^{\text {nd }}$ Session (September 10, 1992).

Mester, Loretta J. "Is the Personal Bankruptcy System Bankrupt?,” Federal Reserve Bank of Philadelphia Business Review (First Quarter 2002).

National Commission on Consumer Finance. Technical Studies, Vol. 5. Washington: U.S. Government Printing Office, 1973.

Nocera, Joseph. A Piece of the Action: How the Middle Class Joined the Money Class. New York: Simon \& Schuster, 1994.

The Nilson Report, various years.

Pence, Karen M. "Foreclosing on Opportunity: State Laws and Mortgage Credit," Review of Economics and Statistics, 88, 1 (February 2006), pp. 177-82.

Peterson, Richard L. "Creditors' Use of Collection Remedies," Journal of Financial Research, 9 (1986), pp. 71-86.

Scott, Robert E. "Rethinking the Regulation of Coercive Creditor Remedies," Columbia Law Review, 89 (1989), pp. 730-89.
Spencer, Jane. "A New Threat to Your Credit Rating — Unpaid Parking Tickets, Library Fees Start to Hurt Consumer Credit as Strapped Cities Seek Payment," Wall Street Journal, January 3, 2006.

Stanley, David T., and Marjorie Girth. Bankruptcy: Problem, Process, and Reform. Washington: The Brookings Institution, 1971.

Villegas, Daniel J., "Regulation of Creditor Practices: An Evaluation of the FTC's Credit Practice Rule," Journal of Economics and Business, 42 (1990), pp. 51-97.

Waggoner, Darren. "Once Viewed as a 'Poison,' Bad-Debt Resales Are Booming," Cards and Payments, 18 (September 2005), pp. 42-45.

Waggoner, Darren. "Is the Party Over for Debt Sellers?" Collections and Credit Risk, 11 (January 2006), pp. 29-34.

Waggoner, Darren. "Banks Merge, Anxiety Grows," Cards and Payments, 18 (November 2005), pp. 38-42.

White, Michele J. "Why Don't More Households File for Bankruptcy?," Journal of Law, Economics and Organization, 14 (1998).

Williams, Winton E. Games Creditors Play. Durham, NC: Carolina Academic Press, 1998. 